\title{
GENETIC ARCHITECTURE OF RELATIVE CELL INJURY AND SOME YIELD RELATED PARAMETERS IN Gossypium hirsutum L.
}

\author{
Muhammad SALMAN ${ }^{1}$, Asif Ali KHAN ${ }^{I}$, Iqrar Ahmad RANA ${ }^{2}$, Rana Haroon MAQSOOD ${ }^{I}$, Muhammad \\ Tehseen AZHAR ${ }^{I^{*}}$
}

${ }^{1}$ University of Agriculture, Department of Plant Breeding \& Genetics, Faisalabad, PAKISTAN

${ }^{2}$ University of Agriculture, Centre of Agricultural Biochemistry \& Biotechnology, Faisalabad, PAKISTAN

*Corresponding author: tehseenpbg@uaf.edu.pk

Received: 31.05 .2016

\begin{abstract}
Although cotton is sun loving crop but its production is adversely affected due to biotic and abiotic stress, heat stress contributed significantly in this loss around the globe. The present research work on heat tolerance in cotton is a step forward to understand the genetic basis of heat tolerance in upland cotton. The presence and identification of genetic variation for certain traits is one of the pre-requisite to start research work. There are several techniques for the screening of germplasm for heat tolerance. Relative cell injury was used for the identification of the most heat tolerant and susceptible cotton genotypes i.e. VH-259, VH-142 and DNH-40, VH-282 respectively. The identified genotypes were used for the development of $F_{1}, F_{2}, \mathbf{B C}_{1}$ and $\mathbf{B C}_{2}$ populations for genetic studies. The biometrical analysis revealed that selected traits i.e. relative cell injury, chlorophyll contents, boll shedding percentage, plant height, number of bolls per plant, number of seeds per boll, seed cotton yield were controlled by additive and non-additive type of gene action including epistatic effects. It is suggested that selection in these populations should be done in later generations for the development of new germplasm with enhanced heat tolerance.
\end{abstract}

Keywords: Generation means analysis, Gene action, Heat stress, Screening, Upland Cotton.

\section{INTRODUCTION}

Upland cotton is an important fiber crop which is cultivated in more than hundred countries and covering more than 32 million hectares worldwide. It is an important source of oil and livestock feed, even as lowprotein food for humans in some third-world countries (Singh et al., 2007). USA, China, India and Pakistan are top four cotton producing countries and collectively provide about $2 / 3$ cotton of the world. Its production accounts for $1.5 \%$ in GDP, $7.1 \%$ in agricultural value addition and it also plays a major role in foreign exchange for Pakistan and during July-March 2014-15, textile industry fetched foreign exchange of 10.22 billion dollars. The cotton crop is planted on an area of 2961 thousand hectares, showing an increase of 5.5 percent over area of i.e. 2806 thousand hectares last year's and its production stood at 13.983 million bales against 12.769 million bales of last year showing an increase of $9.5 \%$ for the year 2014-15 (Govt. of Pakistan, 2014-15).

Production of cotton is adversely effected by various biotic and abiotic stresses among them heat stress is one of the major factors that affects its growth and development which directly effects on yield of seed cotton. Global warming due to increase of greenhouse gases has significantly changed the world climate and this is one of the sources of increase in global temperature by $0.4-0.8{ }^{\circ} \mathrm{C} /$ year. Loss of 4.2 billion dollars was recorded in agriculture sector due to heat and drought stress (Pachauri et al., 2014). This warns the plant breeders and scientists to identify and design strategy that could minimize the losses due to these stresses. High temperature induces irreversible changes/damage to plant development and growth such as wilting of leaf, flower and fruit shedding. This damage depends on intensity and duration of temperature as well as growth stage of plant (Mittler, 2006; Wahid et al., 2007; Viola et al., 2010).

In Pakistan, cotton is grown in the Punjab and Sindh provinces (Ahmad and Makhdum, 1992). In Punjab and Sindh, during plantation, germination and growth stage temperature reaches to $45-50^{\circ} \mathrm{C}$, and this high temperature significantly reduce plant population by reducing germination percentage, poor pollen germination, production of low quality fiber and finally reduction of yield (Rahman et al., 2004). According to some researchers, seedlings and floral stages are the most sensitive stages to high temperature (Howarth and Ougham, 1993; Ismail and Hall, 1998; Foolad, 2005). In addition, high temperatures also exerts adverse effects by modifying physiological functions of cellular organelles while modification in cell membranes either by 
denaturation of proteins or by transformation of saturated fatty acid to unsaturated fatty acid in membrane lipids (Larkindale and Huang, 2004). In fact, high temperature loosens the chemical bonds (covalent or non- covalent bonds) between molecules within membrane and enhances mobility of molecules across membranes. Increase in membrane fluidity can lead to leakage of organic and inorganic solutes that leads to loss of physiological functions of cellular membranes. This membrane stability percentage can be used as important criteria for the identification of heat tolerant and susceptible lines (Wahid et al., 2007), and this techniques has been used by various researches in various crops like cotton (Azhar et al., 2009; Khan et al., 2014), wheat (Blum and Ebercon, 1981; Bajji et al., 2002; Dhanda et al., 2004), rice (Ali et al., 2013) and maize (Naveed et al., 2014).

If temperature exceed from $36^{\circ} \mathrm{C}$, it adversely affects on reproductive phase, including $65-70 \%$ shedding of squares. buds and flowers, pollen sterility and consequently decrease the plant yield (Kittock et al., 1988; Baloch et al., 2000; Liu et al., 2006). Moreover, high temperature slows down rate of photosynthesis and respiration (Christiansen, 1978). The breeding for heat tolerant cotton genotype depends upon the presence of genetic and significant amount of variability in the available germplasm. The susceptibility to high temperatures varies for developmental and reproductive stages in crop plants (Sakata and Higashitani, 2008). Several reports are available about the presence of genetic variation in heat related parameters in various field crops i.e. wheat (Shanahan et al., 1990; Ali and Khan, 2007), rice (Mackill et al., 1982), cowpeas (Mutters and Hall, 1992; El-kholy et al., 1997), and mungbean (Collins et al., 1995). Although information on the occurrence of variability for heat tolerance in crop species is available but this knowledge on genetic basis of that variation is not fully utilized. However a few genetic studies on wheat (Ibrahim and Quick, 2001a, b), cowpea (Ismail and Hall, 1998) and cotton (Trolinder and Shang, 1991; Baloch et al., 2000; Rahman et al., 2004) provide evidence that heat tolerance is genetically controlled, and suggesting the opportunities for further improvement in heat tolerance through selection and breeding.

Keeping in view the impact of heat stress on yield and physiology of cotton plant, the present study was designed to determine the genetic basis of heat tolerance and other economic traits in upland cotton.

\section{MATERIALS AND METHODS}

\section{Assessment of germplasm for relative cell injury $(R C I)$}

Eighty genotypes of upland cotton were collected from various Agricultural Research stations/ institutes of Pakistan to identify heat tolerant and susceptible parents. The collected germplasm was sown on 23 May, 2012 at cotton research farm of the Department of Plant Breeding and Genetics, University of Agriculture, Faisalabad (Pakistan). All cultural and agronomic practices approved by Government of Punjab were adopted to get healthy population. Relative cell injury (RCI) percentage was measured from ten fully developed young leaves during peak flowering season. A steel punch having a diameter of $10 \mathrm{~mm}$ was used for sample collection from selected leaves. Two sets of samples were collected from both sides of midrib of each leaf. One set was used as control and other for heat treatment. Leaf disks were collected at about $12 \mathrm{pm}$ to $2 \mathrm{pm}$ and samples were immediately kept in falcon tubes having $2 \mathrm{ml}$ of distilled water and were taken to laboratory as quickly as possible. They were washed twice with distilled water to remove dust and other inert material present on the leaf surface. After washing, $12 \mathrm{ml}$ of distilled water was added in sterilized falcon tubes and covered with lid to avoid evaporation during heat treatment. One set of falcon was kept at room temperature and other at $50^{\circ} \mathrm{C}$ in water bath for 1 hour (Rahman et al., 2004). After heat treatment, $10 \mathrm{ml}$ of distilled water was added to each tube and kept at $10^{\circ} \mathrm{C}$ for 24 hours to allow diffusion of electrolytes. On the next day, tubes were kept at room temperature and shaken three times for mixing of electrolytes. Initial electrical conductivity (EC) was noted with the help of EC meter. Falcon tubes were autoclaved at $0.10 \mathrm{MPa}$ pressure to release all of electrolytes present in leaf disk. Tubes were placed on working bench when room temperature was attained then relative reading of EC was noted again with the help of same EC meter as used previously (Sullivan, 1972)

Relative cell injury (RCI) percentage was calculated by using the following formula proposed by

$$
\left.\mathrm{RCl} \%=\left[1-\left[\left(1-\left(\mathrm{T}_{1}-\mathrm{T}_{2}\right)\right)\right] /\left(1-\left(\mathrm{C}_{1} / \mathrm{C}_{2}\right)\right)\right]\right] \times 100
$$

Where $\mathrm{T}$ and $\mathrm{C}$ are respective $\mathrm{EC}$ values of heat treated and controlled tubes and subscripts 1 and 2 represent initial and final EC readings, respectively.

\section{Development of various populations for genetic studies}

Two heat tolerant (VH-259 and VH-142) and two heat susceptible genotypes (VH-282 and DNH-40) were selected on the basis of the data recorded for RCI percentage. These four genotypes were sown in cotton growing season 2013 for the development of $F_{1}$ population. During the next cropping season 2013-14, $F_{1}$ generations and their parents were grown in the field for developing back crosse 1 , back cross 2 and $F_{2}$ generations. All preliminary measures were adopted to avoid selfpollination during hybridization.

\section{Assessment of populations for heat stress and other economic traits}

On 7 May 2015 and 1 June 2015, fours parents (VH282, VH-142, DNH-40, and VH-259) along with $\mathrm{F}_{1}, \mathrm{~F}_{2}$, $\mathrm{BC}_{1}$ and $\mathrm{BC}_{2}$ populations from each cross were grown in triplicate using randomized complete block design in field conditions of the department. Each replication was comprised of five rows with ten plants for each of parent, $\mathrm{F}_{1}$, backcross and six rows of each $\mathrm{F}_{2}$ generation. Plant to plant and row to row distance was kept $30 \mathrm{~cm}$ and $75 \mathrm{~cm}$ respectively. Data on cell membrane stability (\%) and Chlorophyll contents (SPAD-502) was recorded during August, 2015 for both late and early sown trial. Data was 
collected during mid-day from all tagged one month old plants (three fully developed leaves from each plant were used). SPAD-502 Chlorophyll meter was placed on each leaf and waited until reading was stabilized. Average of three leaves was used as per plant reading. In addition, data on plant height $(\mathrm{cm})$, boll shedding percentage $(\%)$, number of bolls per plant, number of seeds per boll and seed cotton yield $(\mathrm{g})$ were recorded at maturity from 30 plants of each parent, $F_{1}$, backcrosses while 150 plants of each $\mathrm{F}_{2}$ population.

\section{Statistical Analysis}

Analysis of variance among the generations was conducted as in (Steel et al., 1997). The data collected for the traits showing significant differences, was used to conduct generation means analysis following the method described by (Mather and Jinks, 1982).

\section{RESULTS}

\section{Response of germplasm against heat stress}

Eighty cotton genotypes were grown in field conditions for screening against heat stress using relative cell injury percentage. The mean values of all genotypes under heat stress were given in Table 1. Analysis of variance revealed the presence of significant differences among the genotypes for the trait. Values of RCI\% was ranged from 39.1 to 85.9 in the available germplasm of cotton. In this study two cultivars namely $\mathrm{VH}-259$ and VH-142 having values 39.1 and 40.3 respectively were identified to be most heat tolerant while DNH-40 and VH282 having RCI \% of 85.9 and 83.8 respectively were identified as most heat susceptible genotypes (Table 1).

Table 1. Mean values of 80 genotypes of cotton for RCI \% in green house conditions.

\begin{tabular}{clllllllllll}
\hline $\begin{array}{c}\text { Sr. } \\
\text { No }\end{array}$ & Genotypes & RCI & $\begin{array}{c}\text { Sr. } \\
\text { No }\end{array}$ & Genotypes & RCI & $\begin{array}{c}\text { Sr. } \\
\text { No }\end{array}$ & Genotypes & RCI & $\begin{array}{c}\text { Sr. } \\
\text { No }\end{array}$ & Genotypes & RCI \\
\hline 1 & DNH 40 & 85.9 & 21 & CIM 109 & 77.2 & 41 & NIAB & 71.8 & 61 & VH 281 & 62.4 \\
2 & VH 282 & 83.8 & 22 & FH 114 & 77.2 & 42 & MNH93 & 71.4 & 62 & MNH 147 & 61.9 \\
3 & MNH 465 & 82.5 & 23 & CRWAS 310 & 77.1 & 43 & CIM 70 & 70.8 & 63 & VH-250 & 61.8 \\
4 & CIM 608 & 82.2 & 24 & C 26 & 76.7 & 44 & BH 163 & 70.7 & 64 & MNH 888 & 61.7 \\
5 & MNH 506 & 81.7 & 25 & BH 96 & 76.5 & 45 & NS 131 & 69.0 & 65 & BP 900 & 61.1 \\
6 & CIM 534 & 81.2 & 26 & BH 121 & 76.1 & 46 & FH 113 & 68.8 & 66 & RED ACALA & 60.7 \\
7 & CIM 499 & 81.1 & 27 & FH 2015 & 76.1 & 47 & KZ 191 & 68.2 & 67 & VH 144 & 59.3 \\
8 & VH 291 & 80.6 & 28 & GR 156 & 76.1 & 48 & DNH29 & 68.1 & 68 & B 557 & 58.2 \\
9 & NIAB 86 & 80.6 & 29 & RIBA B50 & 76.0 & 49 & FH 682 & 67.7 & 69 & MNH 554 & 57.7 \\
10 & AA 802 & 79.9 & 30 & NF 801/7 & 75.8 & 50 & BH 160 & 67.3 & 70 & FH 115 & 57.6 \\
11 & KZ 181 & 79.7 & 31 & SV 322 & 75.7 & 51 & VH 297 & 66.2 & 71 & MNH 700 & 57.6 \\
12 & CIM 707 & 79.7 & 32 & CRWAS 134 & 75.4 & 52 & BS 1 & 66.1 & 72 & SLH 257 & 57.6 \\
13 & NIAB 98 & 79.5 & 33 & BH 147 & 74.5 & 53 & CIM 496 & 65.7 & 73 & CRWAS 379 & 56.3 \\
14 & FH 87 & 79.1 & 34 & DPL 70010 & 74.3 & 54 & DPL2775 & 65.0 & 74 & BT 701 & 56.0 \\
15 & NIAB 999 & 78.9 & 35 & FH 942 & 74.2 & 55 & DPL 26 & 64.1 & 75 & VH 141 & 54.4 \\
16 & IR 3701IR 3701 & 78.8 & 36 & CRW AS 5A & 73.5 & 56 & DPL 28 & 63.4 & 76 & BP 630 & 54.0 \\
17 & SV 857 & 78.7 & 37 & VH 61 & 72.5 & 57 & BH 162 & 63.2 & 77 & VH 300 & 52.8 \\
18 & VH 268 & 78.7 & 38 & FH900 & 72.4 & 58 & VH 255 & 63.0 & 78 & Marvi & 49.1 \\
19 & KZ 189 & 78.5 & 39 & FH 4243 & 72.0 & 59 & CRWAS 402 & 62.7 & 79 & VH 142 & 40.3 \\
20 & CIM 448 & 78.1 & 40 & VH 256 & 72.0 & 60 & MNH 786 & 62.6 & 80 & VH 259 & 39.1 \\
\hline
\end{tabular}

\section{Gene action}

The six generations from both crosses were planted in field conditions for the collection of observations on all traits under study. Mean values and ANOVA were biometrically analyzed using generation mean analysis approach proposed by (Mather and Jinks, 1982). The interpretation of the results of each agronomic trait is mentioned in following paragraphs.

\section{Relative Cell Injury}

Mean values of relative cell injury of $F_{1}$ generation was higher than mean values obtained from population of $\mathrm{F}_{2}, \mathrm{BC}_{1}$ and $\mathrm{BC}_{2}$ in normal and heat stress conditions for both the crosses of cotton indicated that heterozygosity could be exploited for decrease of this trait. Mean value for relative cell injury was ranged from 62.83 to 78.53 in this study from six generations i.e. $\mathrm{P}_{1}, \mathrm{P}_{2}, \mathrm{~F}_{1}, \mathrm{~F}_{2}, \mathrm{BC}_{1}$ and $\mathrm{BC}_{2}$ for each cross (Table 2). Analysis of the data by generation mean analysis showed that relative cell injury was under the influence of multiple genes. This trait was controlled by [mjl] in cross-1 in normal conditions while under heat stress condition it was controlled by [mdhjl]. Additive component [d] was more than dominant component [h] for cross-1 under heat stress conditions. Analysis of the data also revealed that duplicate epistasis existed under heat stress conditions because dominant component [h] and dominant $\times$ dominant component [1] have opposite signs. Relative cell injury was controlled by [mhijl] and revealed that for cross- 2 in normal condition duplicate epistasis existed because dominant component [h] and dominant $\times$ dominant component [1] have opposite signs in normal condition for cross- 2 whereas heat stress 
condition of cross-2 it was controlled by [mdhjl]. Additive and duplicate epistasis also plays its role to control this component [d] was higher than dominant component $[\mathrm{h}]$ trait under heat stress condition (Table 3).

Table 2. Generation means for plant height, number of bolls per plant, boll shedding percentage, number of seeds per boll, seed cotton yield, relative cell injury percentage and chlorophyll contents in two crosses VH-282 $\times \mathrm{VH}-142$ and DNH-40 $\times \mathrm{VH}-259$ under normal and heat stress conditions.

\begin{tabular}{|c|c|c|c|c|c|c|c|c|}
\hline \multirow{2}{*}{ Traits } & \multirow{2}{*}{$\begin{array}{l}\text { Stress } \\
\text { Levels }\end{array}$} & \multicolumn{6}{|c|}{ Generation Means } & \multirow{2}{*}{$\begin{array}{c}\text { Pop } \\
\text { Effect }\end{array}$} \\
\hline & & $\mathbf{P}_{1}$ & $\mathbf{P}_{2}$ & $\mathbf{F}_{1}$ & $\mathrm{BC}_{1}$ & $\mathrm{BC}_{2}$ & $\mathbf{F}_{2}$ & \\
\hline \multirow{4}{*}{ RCI } & N1 & 28.30 & 28.45 & 21.86 & 26.66 & 26.57 & 26.97 & $* *$ \\
\hline & H1 & 24.27 & 37.17 & 25.67 & 35.23 & 36.73 & 32.48 & $* *$ \\
\hline & $\mathbf{N 2}$ & 25.36 & 25.32 & 21.47 & 31.27 & 29.94 & 28.34 & $* *$ \\
\hline & $\mathbf{H 2}$ & 24.78 & 35.02 & 25.72 & 33.79 & 33.93 & 32.01 & $* *$ \\
\hline \multirow{4}{*}{$\mathbf{C C}$} & N1 & 30.90 & 30.02 & 28.44 & 31.14 & 30.38 & 29.94 & $* *$ \\
\hline & H1 & 16.56 & 27.80 & 23.40 & 22.89 & 24.54 & 25.78 & $* *$ \\
\hline & $\mathbf{N 2}$ & 30.72 & 31.08 & 30.35 & 30.95 & 30.99 & 30.84 & $* *$ \\
\hline & $\mathbf{H 2}$ & 26.35 & 29.16 & 25.53 & 26.74 & 25.81 & 27.43 & $* *$ \\
\hline \multirow{4}{*}{ PH } & N1 & 109.53 & 107.10 & 112.43 & 103.47 & 107.00 & 106.36 & $* *$ \\
\hline & H1 & 101.47 & 99.57 & 106.47 & 101.60 & 102.33 & 101.48 & $* *$ \\
\hline & N2 & 106.93 & 106.70 & 108.83 & 107.50 & 108.63 & 107.68 & $* *$ \\
\hline & H2 & 102.30 & 94.10 & 102.03 & 100.70 & 93.60 & 107.38 & $* *$ \\
\hline \multirow{4}{*}{$\mathbf{B} / \mathbf{P}$} & N1 & 12.97 & 11.43 & 12.67 & 12.20 & 11.63 & 11.47 & $*$ \\
\hline & H1 & 10.13 & 7.01 & 8.57 & 8.57 & 9.37 & 7.76 & $*$ \\
\hline & N2 & 21.73 & 19.94 & 19.03 & 19.08 & 20.83 & 18.33 & $* *$ \\
\hline & H2 & 12.60 & 11.57 & 11.23 & 11.67 & 11.90 & 11.40 & $* *$ \\
\hline \multirow{4}{*}{ BSP } & N1 & 81.03 & 89.10 & 84.00 & 83.90 & 89.20 & 79.36 & $* *$ \\
\hline & H1 & 81.20 & 89.17 & 85.30 & 82.70 & 88.97 & 79.16 & $* *$ \\
\hline & N2 & 83.47 & 86.30 & 82.70 & 82.67 & 82.40 & 84.09 & $* *$ \\
\hline & H2 & 69.97 & 80.20 & 73.10 & 70.80 & 80.03 & 72.50 & $* *$ \\
\hline \multirow{4}{*}{ NSB } & N1 & 26.60 & 22.83 & 23.40 & 24.10 & 24.93 & 23.21 & $* *$ \\
\hline & H1 & 20.56 & 20.55 & 19.80 & 20.15 & 20.13 & 20.22 & $* *$ \\
\hline & N2 & 24.88 & 24.97 & 23.23 & 24.10 & 24.20 & 24.16 & $* *$ \\
\hline & H2 & 24.17 & 21.50 & 22.70 & 22.91 & 23.53 & 22.20 & $* *$ \\
\hline \multirow{4}{*}{ SCY } & N1 & 50.54 & 34.50 & 46.75 & 35.23 & 35.08 & 41.78 & $* *$ \\
\hline & H1 & 35.49 & 23.69 & 35.47 & 27.98 & 25.08 & 25.13 & $* *$ \\
\hline & N2 & 79.51 & 59.52 & 75.22 & 62.26 & 59.23 & 62.05 & $* *$ \\
\hline & H2 & 43.75 & 34.82 & 38.66 & 36.54 & 36.86 & 39.02 & $* *$ \\
\hline
\end{tabular}

RCI: Relative Cell Injury, CC: Chlorophyll Contents, PH: Plant height, B/P: Number of Bolls per Plant, BSP: Boll Shedding Percentage, NSB: Number of Seeds per Boll, SCY: Seed Cotton Yield,

$\mathrm{N} 1$ and N2: Cross 1 and Cross 2 under normal conditions respectively, $\mathrm{H} 1$ and H2: Cross 1 and Cross 2 under heat stress conditions respectively.

\section{Chlorophyll contents}

Mean values for chlorophyll contents of $\mathrm{F}_{2}$ was higher than $\mathrm{F}_{1}, \mathrm{BC}_{1}$ and $\mathrm{BC}_{2}$ in both the crosses in normal as well as heat stress conditions, so homozygosity could result in improvement of this trait. Chlorophyll contents were ranged from 16.56 to 31.14 in this study conducted in field conditions for both crosses having six generations i.e. $\mathrm{P}_{1}, \mathrm{P}_{2}, \mathrm{~F}_{1}, \mathrm{~F}_{2}, \mathrm{BC}_{1}$ and $\mathrm{BC}_{2}$ (Table 2). Generation mean analysis showed that chlorophyll contents were controlled by polygenes. This trait was controlled by [mdhi] and [mdh] in normal conditions and under heat stress condition respectively in cross-1. Additive component [d] was higher than dominant component [h] in normal and under heat stress conditions. Chlorophyll contents were controlled by $[\mathrm{ml}]$ and $[\mathrm{mdh}]$ in normal conditions and under heat stress conditions respectively in cross-2. Additive component [d] again was higher than dominant component [h] for this trait under heat stress conditions (Table 3).

\section{Plant height}

For plant height under both stress conditions in both crosses, $(\mathrm{VH}-282 \times \mathrm{VH}-142$ was considered as cross-1 while DNH-40 $\times$ VH-259 was cross-2) $\mathrm{F}_{1}$ mean value was higher than $\mathrm{F}_{2}, \mathrm{BC}_{1}$ and $\mathrm{BC}_{2}$ mean values, so heterozygosity could result in taller plants (Table 2).

In this study plant height ranged from 93.60 to $112.43 \mathrm{~cm}$ for both crosses under normal and heat stress conditions in 12 generations (six from each cross i.e. $\mathrm{P}_{1}$, $\mathrm{P}_{2}, \mathrm{~F}_{1}, \mathrm{~F}_{2}, \mathrm{BC}_{1}$ and $\mathrm{BC}_{2}$ ). Generation mean analysis showed that plant height was controlled by polygenes. In cross-1 under normal condition it was controlled by [mdhi], while in heat stress conditions, it was controlled by [mdl] (Table 3). Here dominant component was higher 
than additive component in normal conditions while in cross-2, this trait was controlled by [mdh] in normal condition, but in heat stress condition, it was controlled by [mdhj]. Here additive component was more than dominant component in heat stress. Dominant component was higher than additive component in normal condition. Epistatic components [i], [j] and [1] were also contributing under both conditions.

Table 3. Estimates of the best fit model for generation means parameters ( \pm , standard error) by weighted least squares analysis in respect for plant height, number of bolls per plant, boll shedding percentage, number of seeds per boll, seed cotton yield, relative cell injury percentage and chlorophyll contentsin two crosses VH-282 $\times \mathrm{VH}-142$ and DNH-40 $\times \mathrm{VH}-259$ under normal and heat stress conditions.

\begin{tabular}{|c|c|c|c|c|c|c|c|c|}
\hline \multirow{2}{*}{ Traits } & \multirow{2}{*}{ Stress Condition } & \multicolumn{6}{|c|}{ Genetic Effects } & \multirow{2}{*}{$\mathrm{X}^{2}(\mathrm{DF})$} \\
\hline & & $\mathbf{m} \pm$ S.E. & {$[d] \pm$ S.E. } & {$[\mathbf{h}] \pm$ S.E. } & {$[\mathrm{i}] \pm$ S.E. } & {$[\mathbf{j}] \pm$ S.E. } & {$[\mathbf{l}] \pm$ S.E. } & \\
\hline \multirow{4}{*}{ RCI } & N1 & $71.623 \pm 0.499$ & -- & -- & -- & $0.821 \pm 2.771$ & $6.513 \pm 1.026$ & $0.019(3)$ \\
\hline & H1 & $66.786 \pm 6.226$ & $6.451 \pm 0.554$ & $-15.613 \pm 14.357$ & -- & $-21.411 \pm 3.319$ & $23.157 \pm 8.454$ & $0.871(1)$ \\
\hline & $\mathbf{N 2}$ & $66.170 \pm 6.812$ & -- & $-2.110 \pm 16.310$ & $8.490 \pm 6.783$ & $-3.198 \pm 3.941$ & $14.471 \pm 9.856$ & $0.121(1)$ \\
\hline & H2 & $66.833 \pm 7.166$ & $5.118 \pm 0.635$ & $-9.940 \pm 16.839$ & -- & $-14.078 \pm 4.086$ & $17.384 \pm 10.027$ & $0.809(1)$ \\
\hline \multirow{4}{*}{$\mathrm{CC}$} & N1 & $33.753 \pm 0.356$ & $0.438 \pm 0.126$ & $-5.363 \pm 0.497$ & $-3.325 \pm 0.394$ & -- & -- & $0.774(2)$ \\
\hline & H1 & $20.375 \pm 0.140$ & $9.837 \pm 0.136$ & $-0.700 \pm 0.264$ & -- & -- & -- & $2.374(3)$ \\
\hline & N2 & $30.991 \pm 0.123$ & -- & -- & -- & -- & $-0.575 \pm 0.286$ & $2.242(4)$ \\
\hline & H2 & $27.764 \pm 0.148$ & $1.436 \pm 0.147$ & $-2.211 \pm 0.268$ & -- & -- & -- & $0.311(3)$ \\
\hline \multirow{4}{*}{ PH } & N1 & $94.224 \pm 2.045$ & $1.142 \pm 0.537$ & $18.154 \pm 2.568$ & $14.063 \pm 2.158$ & -- & -- & $0.202(2)$ \\
\hline & H1 & $100.398 \pm 0.368$ & $0.938 \pm 0.432$ & -- & -- & -- & $5.992 \pm 0.799$ & $0.295(3)$ \\
\hline & $\mathbf{N 2}$ & $106.823 \pm 0.527$ & $0.160 \pm 0.528$ & $2.025 \pm 0.947$ & -- & -- & -- & $0.206(3)$ \\
\hline & H2 & $98.236 \pm 0.276$ & $4.098 \pm 0.282$ & $3.864 \pm 0.474$ & -- & $-36.183 \pm 2.904$ & -- & $0.419(2)$ \\
\hline \multirow{4}{*}{$\mathbf{B} / \mathbf{P}$} & N1 & $12.200 \pm 0.184$ & $0.767 \pm 0.184$ & $-2.449 \pm 0.819$ & -- & $-0.872 \pm 0.700$ & $2.916 \pm 0.842$ & $1.226(1)$ \\
\hline & H1 & $8.560 \pm 0.107$ & $1.577 \pm 0.176$ & -- & -- & -- & -- & $0.017(4)$ \\
\hline & $\mathbf{N 2}$ & $19.070 \pm 0.267$ & $0.892 \pm 0.175$ & -- & $1.760 \pm 0.336$ & $3.592 \pm 0.853$ & $-0.039 \pm 0.357$ & $0.014(1)$ \\
\hline & H2 & $12.086 \pm 0.479$ & $0.512 \pm 0.141$ & $-0.857 \pm 0.638$ & $-0.005 \pm 0.523$ & -- & -- & $0.006(2)$ \\
\hline \multirow{4}{*}{ BSP } & N1 & $83.973 \pm 0.192$ & $4.033 \pm 0.247$ & -- & $1.102 \pm 0.331$ & $27.748 \pm 1.053$ & -- & $0.073(2)$ \\
\hline & H1 & $80.957 \pm 0.932$ & $3.982 \pm 0.238$ & $4.430 \pm 1.122$ & $4.273 \pm 0.982$ & $29.019 \pm 1.271$ & -- & $1.971(1)$ \\
\hline & $\mathbf{N 2}$ & $82.698 \pm 0.203$ & $1.475 \pm 0.222$ & -- & $2.187 \pm 0.342$ & -- & -- & $0.267(3)$ \\
\hline & $\mathbf{H} 2$ & $53.211 \pm 2.401$ & $5.116 \pm 0.238$ & $50.465 \pm 5.537$ & -- & $25.293 \pm 1.291$ & $-30.577 \pm 3.271$ & $0.572(1)$ \\
\hline \multirow{4}{*}{ NSB } & N1 & $24.730 \pm 0.165$ & $1.852 \pm 0.163$ & $-1.301 \pm 0.298$ & -- & -- & -- & $0.177(3)$ \\
\hline & H1 & $20.559 \pm 0.221$ & -- & $-0.750 \pm 0.416$ & -- & -- & -- & $0.053(4)$ \\
\hline & N2 & $24.950 \pm 0.148$ & -- & $-1.659 \pm 0.285$ & -- & -- & -- & $0.272(4)$ \\
\hline & H2 & $22.831 \pm 0.102$ & $1.327 \pm 0.146$ & -- & -- & -- & -- & $0.364(4)$ \\
\hline \multirow{4}{*}{ SCY } & N1 & $29.724 \pm 4.691$ & $8.017 \pm 0.738$ & $5.010 \pm 10.778$ & -- & $-29.442 \pm 2.654$ & $12.016 \pm 6.527$ & $1.006(1)$ \\
\hline & H1 & $41.063 \pm 5.319$ & $5.900 \pm 0.733$ & $-46.754 \pm 12.252$ & -- & $-11.896 \pm 2.963$ & $41.164 \pm 7.356$ & $0.982(1)$ \\
\hline & N2 & $76.003 \pm 7.516$ & $9.993 \pm 0.640$ & $-54.178 \pm 17.283$ & -- & $-25.629 \pm 3.951$ & $53.395 \pm 10.14$ & $1.231(1)$ \\
\hline & H2 & $33.682 \pm 6.339$ & $4.465 \pm 0.630$ & $6.451 \pm 14.574$ & -- & $-13.256 \pm 3.371$ & $-1.470 \pm 8.591$ & $0.892(1)$ \\
\hline
\end{tabular}

RCI: Relative Cell Injury, CC: Chlorophyll Contents, PH: Plant height, B/P: Number of Bolls per Plant, BSP: Boll Shedding Percentage, NSB: Number of Seeds per Boll, SCY: Seed Cotton Yield, N1 and N2: Cross 1 and Cross 2 under normal conditions respectively, H1 and H2: Cross 1 and Cross 2 under heat stress conditions respectively.

\section{Number of bolls per plant}

For number of bolls per plant in $\mathrm{F}_{1}$ generation mean value was higher than $\mathrm{F}_{2}, \mathrm{BC}_{1}$ and $\mathrm{BC}_{2}$ for cross- 1 and cross-2 in normal and heat stress conditions. Heterozygosity could result in improvement of this trait (Table 2). In this study number of bolls per plant was ranged from 7.01 to 21.73 for both crosses under normal and heat stress conditions, for 12 generations (six from each cross i.e. $\mathrm{P}_{1}, \mathrm{P}_{2}, \mathrm{~F}_{1}, \mathrm{~F}_{2}, \mathrm{BC}_{1}$ and $\mathrm{BC}_{2}$ ).

Generation mean analysis showed that this trait was controlled by polygenes. In cross- 1 under normal condition it was controlled by [mdhjl], while it was controlled by [md] in heat stress conditions. Here dominant component was negative, showing that genes responsible for decrease of this trait are dominant over the genes increasing the trait. In cross-2, this trait was controlled by [mdijl] in normal condition, while it was controlled by [mdhi] in heat stress condition. Again additive component was negative and showing the same results as noted in cross-1 in normal conditions. The results of cross-1 under normal condition revealed that duplicate epistasis existed as [h] and [1] showed the presence of opposite signs (Table 3 ).

\section{Boll shedding percentage}

For boll shedding percentage $\mathrm{inF}_{1}$ generation was higher than $\mathrm{F}_{2}, \mathrm{BC}_{1}$ and $\mathrm{BC}_{2}$ for both the crosses under normal and stress conditions and heterozygosity could result in increase of boll shedding, so homozygosity should be preferred to decrease boll shedding. Boll shedding percentage was ranged from 69.97 to 89.20 for cross- 1 and 2 under normal and heat stress conditions (Table 2).

Generation mean analysis showed that this trait was controlled by polygenes. In cross-1 under normal condition it was controlled by [mdij], while it was 
controlled by [mdhij] in heat stress condition. Here epistatic component [i] was again positive. In cross-2, boll shedding percentage was controlled by [mdi] in normal condition, while [mdhjl] in heat stress condition. In heat stress condition for both the crosses dominance component was more than additive component. The analysis of cross- 2 in heat stress condition revealed the presence of duplicate epistasis due to positive and negative signs of [h] and [1] respectively. This observation indicated that epistatic component [i] played its role in controlling the boll shedding percentage in normal condition for both the crosses whilst for cross 1 in heat stress conditions (Table 3).

\section{Number of seeds per boll}

For number of seeds per boll mean value of $F_{1}$ was higher than population of $\mathrm{F}_{2}, \mathrm{BC}_{1}$ and $\mathrm{BC}_{2}$ in both crosses. The range for mean value for number of seeds per boll was 19.80 to 26.60 under normal and heat stress conditions for cross-1 and cross-2 from six generations i.e. $\mathrm{P}_{1}, \mathrm{P}_{2}, \mathrm{~F}_{1}, \mathrm{~F}_{2}, \mathrm{BC}_{1}$ and $\mathrm{BC}_{2}$ of each cross (Table 2). Generation mean analysis showed that this trait was controlled by polygenes. It was controlled by [mdh] and [mh] under normal condition and heat stress condition in cross-1 respectively. In cross-1, additive component [d] was higher than dominance component [h] in normal conditions. In cross-2, this trait was controlled by [mh] in normal conditions, while [md] in heat stress condition (Table 3).

\section{Seed cotton yield}

For seed cotton yield, mean value of $F_{1}$ was higher than $\mathrm{F}_{2}, \mathrm{BC}_{1}$ and $\mathrm{BC}_{2}$ population in normal and heat stress condition in both crosses revealed that heterozygosity could be amenable for this trait. The range for mean value for seed cotton yield was 23.69 to 79.51 under normal and heat stress conditions for both crosses from six generations i.e. $\mathrm{P}_{1}, \mathrm{P}_{2}, \mathrm{~F}_{1}, \mathrm{~F}_{2}, \mathrm{BC}_{1}$ and $\mathrm{BC}_{2}$ for each cross (Table 2).Generation mean analysis showed that seed cotton yield was under the influence of multiple genes and controlled by [mdhjl] in cross- 1 and cross- 2 in normal and heat stress conditions. Additive component [d] was more than dominant component [h] for cross-1 in both conditions and for cross-2 only in normal condition. Dominant component [h] was higher than additive component $[\mathrm{d}]$ for cross-2 under heat stress condition.

The results for this trait revealed that dominant component [h] and dominant $\times$ dominant component [1] have same signs, which indicate that complementary epistasis also involved in the inheritance of this trait in normal condition for cross- 1 . The analysis for this trait also revealed that duplicate epistasis exists because dominant component $[\mathrm{h}]$ and dominant $\times$ dominant component [1] have opposite signs for cross-2 in normal and heat stress condition and cross- 1 under heat stress condition (Table 3).

\section{DISCUSSION}

Temperature is a physical parameter that influences proteins and membranes structures through simple thermodynamic effects. Usually these influences are rapid and every molecule can be affected by temperature. It is documented and reported that shifts in climatic temperature can be perceived by cells in terms of changes in membrane rigidity (Vigh et al., 2007a b). High temperatures cause considerable pre- and post-harvest damages including scorching and sun burns of leaves, branches, stems, leaf senescence and abscission, shoot and root growth inhibition, fruit discoloration and damage, and reduction in yield of field crops (Vollenweider and Günthardt Goerg, 2005). Plants respond to stress through physiological and biochemical processes resulting in alteration of gene expression (Wahid et al., 2007; Chaves et al., 2009; Payton et al., 2011).

Although adverse temperatures can affect all stages of development, the cotton crop seems to be particularly sensitive to adverse temperatures during reproductive phase. It was reported that there was no clear consensus about the optimum temperature for growth and development of cotton, as plant response varies with plant developmental stage and environment in which cultivar was developed (Oosterhuis, 2002; Kumar et al., 2012; Sezener et al., 2015). Relative cell injury has been considered as a reliable parameter for screening against abiotic stress tolerance (Shafeeq and Zafar, 2006; Khan et al., 2008; Moussa and Abdel-Aziz, 2008; Azhar et al., 2009; Brito et al., 2011). Two identified tolerant genotypes $\mathrm{VH}-259$ and $\mathrm{VH}-142$ could be used in further breeding programs planned to improvise heat stress. These genotypes could be recommended for heat stress areas.

It was suggested that all the traits were controlled by additive, dominance and epistatic type of gene action. It could be suggested that selection should be done in later generations in order to improve these traits. It was also noted that number of bolls per plant, boll shedding percentage and relative cell injury percentage were controlled by duplicate type of epistasis as signs of [h] and [1] were opposite for these traits, while seed cotton yield showed complementary type of epistasis as signs of [h] and [1] were similar. Similar kind of results were presented by (Ahmad et al., 2009; Khan et al., 2009; Ullah et al., 2010; Gillani et al., 2015; Saleem et al., 2015; Shakeel et al., 2015) while contradictory results were presented by (Farooq et al., 2011; Ghobadi et al., 2011; Khan and Qasim, 2012; Iqbal et al., 2013).

\section{CONCLUSION}

Two identified tolerant genotypes $\mathrm{VH}-259$ and $\mathrm{VH}-$ 142 could be used in further breeding programs. All the traits under study showed complex type of gene action. So it could be suggested that selection should be done in later generations in order to improve these traits. This $F_{2}$ population could be used as good source population for further breeding programs focusing on heat stress tolerance. 


\section{ACKNOWLEDGEMENT}

The authors are thankful to Higher Education Commission, Pakistan for providing funds to conduct this study.

\section{LITERATURE CITED}

Ahmad, M. and M.I. Makhdum. 1992. Effects of salinitysodicity on different phases of cotton plant, its fibre quality and oil contents-a review. Agr. Rev. 13:107-118.

Ahmad, R.T., T.A. Malik, I.A. Khan and M.J. Jaskani. 2009. Genetic analysis of some morpho-physiological traits related to drought stress in cotton (Gossypium hirsutum). Int. J. Agric. Biol. 11:235-240.

Ali, M.A. and I.A. Khan. 2007. Assessment of genetic variation and inheritance mode of some metric traits in cotton (Gossypium hirsutum L.). J. Agric. Social Sci. 3:112-116.

Ali, M.K., A. Azhar and S. Galani. 2013. Response of rice (Oryza sativa L.) under elevated temperature at early growth stage: Physiological markers. Russian J. Agric. Socio-Eco. Sciences 20:11-19.

Azhar, F.M., Z. Ali, M.M. Akhtar, A.A. Khan and R. Trethowan. 2009. Genetic variability of heat tolerance, and its effect on yield and fibre quality traits in upland cotton (Gossypium hirsutum L.). Plant Breed. 128:356-362.

Azhar, F.M., Z. Ali, M.M. Akhtar, A.A. Khan and R. Trethowan. 2009. Genetic variability of heat tolerance, and its effect on yield and fibre quality traits in upland cotton (Gossypium hirsutum L.). Plant Breed. 128:356-362.

Bajji, M., J.-M. Kinet and S. Lutts. 2002. The use of the electrolyte leakage method for assessing cell membrane stability as a water stress tolerance test in durum wheat. Plant Growth Regul. 36:61-70.

Baloch, M.J., A.R. Lakho, R. Rind and H. Bhutto. 2000. Screening of cotton genotypes for heat tolerance via in vitro gametophytic selection technique. Pak. J. Biol. Sci 3:20372038.

Blum, A. and A. Ebercon. 1981. Cell membrane stability as a measure of drought and heat tolerance in wheat. Crop Sci. 21:43-47.

Brito, G.G.d., V. Sofiatti, M.M.d.A. Lima, L.P.d. Carvalho and J.L.d. Silva Filho. 2011. Physiological traits for drought phenotyping in cotton. Acta Sci. Agron. 33:117-125.

Chaves, M.M., J. Flexas and C. Pinheiro. 2009. Photosynthesis under drought and salt stress: regulation mechanisms from whole plant to cell. Ann. Bot. 103:551-560.

Christiansen, M.N. 1978. The physiology of plant tolerance to temperature extremes, Crop tolerance to suboptimal land conditions, USA, pp. 173-191.

Collins, G.G., X.L. Nie and M.E. Saltveit. 1995. Heat shock proteins and chilling sensitivity of mung bean hypocotyls. J. Exp. Bot. 46:795-802.

Dhanda, S., G. Sethi and R. Behl. 2004. Indices of drought tolerance in wheat genotypes at early stages of plant growth. J. Agron. Crop Sci. 190:6-12.

El-kholy, A.S., A.E. Hall and A.A. Mohsen. 1997. Heat and chilling tolerance during germination and heat tolerance during flowering are not associated in cowpea. Crop Sci. 37:456-463.

Farooq, J., I. Khaliq, M. Kashif, Q. Ali and S. Mahpara. 2011. Genetic analysis of relative cell injury percentage and some yield contributing traits in wheat under normal and heat stress conditions. Chil. J. Agric. Res. 71:511-520.

Foolad, M.R. 2005. Breeding for abiotic stress tolerances in tomato, Abiotic stresses: plant resistance through breeding and molecular approaches. The Haworth Press Inc., USA, pp. 613-684.
Ghobadi, M., S. Khosravi, D. Kahrizi and F. Shirvani. 2011. Study of water relations, chlorophyll and their correlations with grain yield in wheat (Triticum aestivum L.) genotypes. World Acad. Sci. Eng. Technol. 78:582-585.

Gillani, S.M.N., R.M. Iqbal, M. Akram, F. Ajmal, M.A. Wasim and M. Ijaz. 2015. Performance of cotton (Gossypium hirsutum L) through foliar application of growth promoters. Pak. J. Life Soc. Sci. 13:20-26.

Govt. of Pakistan. 2014-15. Pakistan Economic Survey, in: Ministry of Finance, E.A.s.W. (Ed.), Islamabad.

Howarth, C.J. and H.J. Ougham. 1993. Gene expression under temperature stress. New Phytol. 125:1-26.

Ibrahim, A.M.H. and J.S. Quick. 2001a. Genetic control of high temperature tolerance in wheat as measured by membrane thermal stability. Crop Sci. 41:1405-1407.

Ibrahim, A.M.H. and J.S. Quick. 2001b. Heritability of heat tolerance in winter and spring wheat. Crop Sci. 41:14011405.

Iqbal, M., M. Naeem, M. Rizwan, W. Nazeer, M.Q. Shahid, U. Aziz, T. Aslam and M. Ijaz. 2013. Studies of genetic variation for yield related traits in upland cotton. AmericanEurasian J. Agric. Environ. Sci. 13:611-618.

Ismail, A.M. and A.E. Hall. 1998. Positive and potential negative effects of heat-tolerance genes in cowpea. Crop Sci. 38:381-390.

Khan, A.I., I.A. Khan and H.A. Sadaqat. 2008. Heat tolerance is variable in cotton (Gossypium hirsutum L.) and can be exploited for breeding of better yielding cultivars under high temperature regimes. Pak. J. Bot. 40:2053-2058.

Khan, N., F.M. Azhar, A.A. Khan and R. Ahmad. 2014. Measurement of canopy temperature for heat tolerance in upland cotton: variability and its genetic basis. Pak. J. Agr. Sci. 51:369-375.

Khan, N.U., G. Hassan, K.B. Marwat, M.B. Kumbhar, I. Khan, Z.A. Soomro, M.J. Baloch and M.Z. Khan. 2009. Legacy study of cottonseed traits in upland cotton using Griffing's combining ability model. Pak. J. Bot. 41:131-142.

Khan, T.M. and M.U. Qasim. 2012. Genetic studies of yield traits in cotton (Gossypium hirsutum L.). J. Agric. Res. 50:21-28.

Kittock, D.L., E.L. Turcotte and W.C. Hofmann. 1988. Estimation of heat tolerance improvement in recent American pima cotton cultivars. J. Agron. Crop Sci. 161:305-309.

Kumar, S.V., D. Lucyshyn, K.E. Jaeger, E. Alós, E. Alvey, N.P. Harberd and P.A. Wigge. 2012. Transcription factor PIF4 controls the thermosensory activation of flowering. Nature 484:242-245.

Larkindale, J. and B. Huang. 2004. Changes of lipid composition and saturation level in leaves and roots for heat-stressed and heat-acclimated creeping bentgrass (Agrostis stolonifera). Environ. Exp. Bot. 51:57-67.

Liu, Z., Y.L. Yuan, S.Q. Liu, X.N. Yu and L.Q. Rao. 2006. Screening for high temperature tolerant cotton cultivars by testing in vitro pollen germination, pollen tube growth and boll retention. J. Integr. Plant Biol. 48:706-714.

Mackill, D.J., W.R. Coffman and J.N. Rutger. 1982. Pollen shedding and combining ability for high temperature tolerance in rice. Crop Sci. 22:730-733.

Mather, K. and J.L. Jinks. 1982. The study of continuous variation. Chapman and Hall, UK.

Mittler, R. 2006. Abiotic stress, the field environment and stress combination. Trends Plant Sci. 11:15-19.

Moussa, H.R. and S.M. Abdel-Aziz. 2008. Comparative response of drought tolerant and drought sensitive maize genotypes to water stress. Aust. J. Crop Sci. 1:31-36. 
Mutters, R.G. and A.E. Hall. 1992. Reproductive responses of cowpea to high temperature during different night periods. Crop Sci. 32:202-206.

Naveed, S., M. Aslam, M.A. Maqbool, S. Bano, Q.U. Zaman and R.M. Ahmad. 2014. Physiology of high temperature stress tolerance at reproductive stages in maize. J. Anim. Plant Sci. 24:1141-1145.

Oosterhuis, D.M. 2002. Day or night high temperatures: A major cause of yield variability. Cotton Grower 46:8-9.

Pachauri, R.K., M.R. Allen, V.R. Barros, J. Broome, W. Cramer, R. Christ, J.A. Church, L. Clarke, Q. Dahe and P. Dasgupta. 2014. Climate change 2014: synthesis report. contribution of working groups I, II and III to the fifth assessment report of the intergovernmental panel on climate change, Switzerland.

Payton, P., K.R. Kottapalli, H. Kebede, J.R. Mahan, R.J. Wright and R.D. Allen. 2011. Examining the drought stress transcriptome in cotton leaf and root tissue. Biotechnol. Lett. 33:821-828.

Rahman, H., S.A. Malik and M. Saleem. 2004. Heat tolerance of upland cotton during the fruiting stage evaluated using cellular membrane thermostability. Field Crops Res. 85:149158.

Rahman, H., S.A. Malik and M. Saleem. 2004. Heat tolerance of upland cotton during the fruiting stage evaluated using cellular membrane thermostability. Field Crops Res. 85:149158.

Rahman, H., S.A. Malik and M. Saleem. 2005. Inheritance of seed physical traits in upland cotton under different temperature regimes. Span. J. Agric. Res. 3:225-231.

Sakata, T. and A. Higashitani. 2008. Male sterility accompanied with abnormal anther development in plants-genes and environmental stresses with special reference to high temperature injury. Int. J. Plant Dev. Biol. 2:42-51.

Saleem, M.A., T.A. Malik and A. Shakeel. 2015. Genetics of physiological and agronomic traits in upland cotton under drought stress. Pak. J. Agri. Sci. 52:317-324.

Sezener, V., H. Basal, C. Peynircioglu, T. Gurbuz and K. Kizilkaya. 2015. Screening of cotton cultivars for drought tolerance under field condition. Turk. J. Field Crops 20:223232.
Shafeeq, S. and Y. Zafar. 2006. Genetic variability of different wheat (Triticum aestivum L.) genotypes/cultivars under induced water stress. Pak. J. Bot. 38:1671-1678.

Shakeel, A., M.M. Sheraz, A. Saeed, I. Ali, W. Nazeer, Z. Amin and A. Ammar. 2015. Estimation of combining ability and heterotic potential for within-boll yield traits under leaf curling disease infestation in cotton. Turk. J. Field Crops 20:44-50.

Shanahan, J.F., I.B. Edwards, J.S. Quick and J.R. Fenwick. 1990. Membrane thermostability and heat tolerance of spring wheat. Crop Sci. 30:247-251.

Singh, R.P., P.V. Prasad, K. Sunita, S. Giri and K.R. Reddy. 2007. Influence of high temperature and breeding for heat tolerance in cotton: a review. Adv. Agron. 93:313-385.

Steel, R.G., J.H. Torrie and D.A. Dickey. 1997. Principles and procedures of statistics: A biological approach, $3^{\text {ed }}$ ed. McGraw-Hill, USA.

Sullivan, C.Y. 1972. Mechanisms of heat and drought resistance in grain sorghum and methods of measurement. Sorghum in Seventies. Oxford \& IBH Pub. Co.

Trolinder, N.L. and X. Shang. 1991. In vitro selection and regeneration of cotton resistant to high temperature stress. Plant Cell Rep. 10:448-452.

Ullah, S., A.S. Khan, A. Raza and S. Sadique. 2010. Gene action analysis of yield and yield related traits in spring wheat (Triticum aestivum). Int. J. Agric. Biol. 12:125-128.

Vigh, L., I. Horvath, B. Maresca and J.L. Harwood. 2007a. Can the stress protein response be controlled by 'membrane-lipid therapy'? Trends Biochem. Sci. 32:357-363.

Vigh, L., Z. Torok, G. Balogh, A. Glatz, S. Piotto and I. Horvath. 2007b. Membrane-regulated stress response, Molecular Aspects of the Stress Response: Chaperones, Membranes and Networks. Springer, USA, pp. 114-131.

Viola, F.M., S.L.D. Paiva and M.A. Savi. 2010. Analysis of the global warming dynamics from temperature time series. Ecol. Model. 221:1964-1978.

Vollenweider, P. and M.S. Günthardt Goerg. 2005. Diagnosis of abiotic and biotic stress factors using the visible symptoms in foliage. Environ. Pollut. 137:455-465.

Wahid, A., S. Gelani, M. Ashraf and M.R. Foolad. 2007. Heat tolerance in plants: an overview. Environ. Exper. Bot. 61:199-223. 